\title{
Tales of Antifascism: International Survivors' Organizations during the Cold War
}

\author{
Maximilian Becker \\ Austrian Academy of Science, Institute of Culture Studies and Theatre \\ History, Vienna, Austria \\ maximilian.becker@oeaw.ac.at
}

\begin{abstract}
During the Cold War, international associations of resistance veterans were important transnational actors. Split along the political fault lines, an 'antifascist' stance was crucial to them, both in their memories of resistance against Nazi Germany and in their involvement in the propaganda campaigns of the Cold War. Due to its manifold activities, the pro-communist Fédération Internationale des Résistants (FIR) was the most important of these international associations. Liberal and anti-communist organizations, like the Fédération Internationale Libre des Déportés et Internés de la Résistance (FILDIR), formed the counterpart to the FIR. These organizations will serve as a point of comparison. This study transcends the prevailing national perspective, instead investigating the transnational memory of the survivors. It goes on to examine the consequences of the political changes in the USSR after Stalin's death in March 1953, and Khrushchev's 'secret speech' as well as the Hungarian Uprising and its suppression in 1956.
\end{abstract}

\section{Keywords}

antifascism - resistance - transnationalism - survivors - communism - Fédération Internationale des Résistants (FIR) - Fédération Internationale Libre des Déportés et Internés de la Résistance (FILDIR)

In present-day usage, the term 'survivor' usually refers to Jews who survived the Holocaust, and it is these individuals who are nowadays held centrally in memory. This was not always so. In the immediate postwar period, resistance

(C) MAXIMILIAN BECKER, 2020|| DOI:10.1163/22116257-09010009

This is an open access article distributed under the terms of the prevailing CC-BY-NC license at the time of publication. 
veterans and those who had been persecuted for political reasons had for a short period wide influence both politically and within society. The first postwar governments of Europe often came from the resistance, and survivors made up a considerable number of members of parliaments or the parties themselves, although this did not mean that they were engaging in politics for the survivors. ${ }^{1}$ Not only did they outnumber the Jewish returnees, but they experienced less obstacles in returning to a more or less 'normal' life and were better positioned politically. ${ }^{2}$ While the Jewish communities had been destroyed during the Holocaust and those who had managed to survive were often the only one left of their whole family, those persecuted for political reasons commonly returned home to their waiting loved ones.

After liberation, resistance veterans, camp survivors and former political prisoners joined together in associations; political convictions played no role at first and the common experience of persecution and resistance had a unifying effect. $^{3}$ The first international survivors' and veterans' associations emerged. These representative 'antifascists' also dominated how the Second World War was collectively remembered into the 1960 s, when the memory of the war began to change, a process which lasted until the end of the Cold War and beyond, and which at the end of the 1980s had seized the whole continent. ${ }^{4}$

In the emerging national master narratives, survivors played a central role: in addition to a heroic memory of resistance that emerged in almost all European countries, the focus was on national, collective victims, with political deportation, especially in France, becoming the central crystallization point of collective memory. By contrast, the memory of the extermination of the Jews played barely a role outside the Jewish communities. ${ }^{5}$

While memory studies and research on the survivors' history often focus on national contexts, this study will transcend the national level by looking on international survivors' organizations. Did a transnational memory of antifascism emerge, despite the fissures of the Cold War? To answer this, we need to determine

1 Lutz Raphael, Imperiale Gewalt und mobilisierte Nation: Europa 1914-1945 (München: Beck, 2011), $175^{-176 .}$

2 Hagit Lavski, New beginnings: Holocaust survivors in Bergen-Belsen and the British zone in Germany, 1945-1950 (Detroit: Wayne State University Press, 2002).

3 A short overview of these associations can be found in Katharina Stengel, Hermann Langbein: Ein Auschwitz-Überlebender in den erinnerungspolitischen Konflikten der Nachkriegszeit, (Frankfurt a.M./New York: Campus-Verlag, 2012), 108-142.

4 Etienne François, 'Meistererzählungen und Dammbrüche: Die Erinnerung an den Zweiten Weltkrieg zwischen Nationalisierung und Universalisierung,' in Mythen der Nationen: 1945 Arena der Erinnerungen, vol. 1, ed. Monika Flacke (Mainz: von Zabern, 2004), 13-28.

5 Alon Confino, 'Remembering the Second World War, 1945-1965: Narratives of Victimhood and Genocide,' Cultural Analysis 4 (2005), 46-75. 
how the survivors' organizations remembered the resistance on a transnational, European level. Therefore, a transnational perspective has to be taken. This will be done by focusing on the pro-communist Fédération Internationale des Résistants [FIR; International Federation of Resistance Fighters], which had members on both sides of the Iron Curtain and played a crucial role within the survivors' movement, not least by initiating the foundation of most of the international committees of former concentration camp inmates.

Furthermore, this study will explore how the memory of resistance informed and motivated the survivors' postwar activities. Research on leftwing survivors' organizations has often misinterpreted their intentions as simply promoting the communist cause or left-wing extremism. Taking up Mary Fulbrook's considerations that the past is not just memory, but has to be seen 'as an important and essential part of a later present', ${ }^{6}$ my hypothesis is that it was precisely their experiences during the Second World War which led them in their post-1945 activities. Their memories were used to legitimate this engagement. How did their resistance activities shape the ways in which they later saw themselves? How far was this understanding culturally shaped - by commemorations, speeches, festivals and exhibitions? Different and changing meanings of antifascism were important in these memories. The analysis of these understandings will shed light on the conflicts between the survivors caused by the fissures of the Cold War.

\section{International Survivors' Organizations}

In February 1946 delegates of survivors' organizations from fifteen European countries both from the East and from the West met in Warsaw to discuss the foundation of an international organization of camp survivors. Among the participants were such famous persons as the later General Secretary of the Italian Communist Party Luigi Longo, who had worked in the Comintern in the 1930s, and the Spaniard Manuel Razola, who in the late 196os published an account about the fate of Spanish prisoners in Mauthausen. In April 1947 they established the Fédération Internationale des Anciens Prisonniers Politiques [FIAPP; International Federation of Former Political Prisoners]. It was an umbrella organization of national associations from both the East and the West. Although a non-partisan organization, communists dominated the leading bodies from the beginning. In the FIAPP's first years, the Polish association

6 Mary Fulbrook, Erfahrung, Erinnerung, Geschichtsschreibung: Neue Perspektiven auf die deutschen Diktaturen (Göttingen: Wallstein, 2016), 8. 
of former political prisoners was the most important organization as the FIAPP had its headquarters in Warsaw. However, from 1948, with the reemerging Cold War, this began to change. From the early 1950s, the Soviet Union set the tone in the FIAPP. The Soviet General Aleksandr Gundorov was vice president until 1959 - the 'grey eminence' of the FIAPP - which in early July 1951 was reorganized into the Fédération Internationale des Résistants (FIR). ${ }^{7}$ Gundorov was an Old Bolshevik, a member of the Party since March 1915. He fought in the Russian Civil War and made a career in the Corps of Engineers of the Red Army. In 1937, when the purges reached their peak, he became commander of the War Engineer School in Moscow. When Nazi Germany attacked the Soviet Union in 1941 he was appointed chairman of the All-Slavic Committee, a propaganda organization whose goal was to activate the resistance in the German-occupied Eastern European countries and to encourage partisan and sabotage actions in the German-occupied Western Soviet territories. Thus, Gundorov could establish close contacts to Communist Party functionaries in Slavic countries. Furthermore, in 1942 Gundorov had been commander of several armies of engineers, but according to his own account he was often in Moscow due to his function as chairman of the All-Slavic Committee. In September 1942 he was moved to the Air Defence Command in Moscow. He became inspector general of the Engineer Troops in 1944 and retired in 1951.

The early Cold War had a serious impact on the survivors' organizations. When the Communists took power, the associations in the eastern states were caught up in the maelstrom of Stalinist purges and the diverse organizations were merged. As well as concentration camp survivors, former partisans and veterans of the regular armies were now also among the members.

These developments also had serious consequences for the FIAPP. Starting in the summer of 1947, the Soviet Union attempted to enlist the FIAPP in its campaign against the Marshall Plan. FIAPP plans to document the National Socialist crimes was therefore no longer appropriate and the intended publication of several volumes of survivors' statements and documents had to be abandoned. ${ }^{8}$ On the whole, the FIAPP changed within a short period of time from an interest group representing survivors to a pure propaganda apparatus in the service of the Soviets. In addition to the economic integration of Western Europe through the Marshall Plan, the FIAPP criticized, among other things,

7 A. Gundorov: Avtobiografija, 20.09.1967, fond 9564, opis 1, dela 1, Gosudarstvennyj arkhiv Rossijskoj Federatsii, Moscow (henceforth: GARF).

8 Commission de l'information, de la propagande et des rapports culturels: Remarques sur l'ordre du jour, 15.-19.02.1948, 22508/2, Dokumentationsarchiv Österreichischer Widerstand, Vienna (henceforth: DÖW). 
the Western Allies' policy toward Germany and the armament in the West the North Atlantic Treaty was founded in the spring of 1949 - but refrained from any critical remarks about the situation in the Soviet-dominated part of the continent. ${ }^{9}$ Central to the FIAPP's campaigns was the notion of peace which was the most important topic of Soviet propaganda since 1948, with the 'struggle for peace' being a key feature of Soviet foreign policy. ${ }^{10}$ The aim of the 'struggle for peace' was twofold. On the one hand it presented the Stalinist regimes as 'peace-loving' and should mask their own armament. Thus, the Soviet atomic bomb was never a theme. The most famous campaign, the Stockholm Appeal of the World Peace Council (WPC) in 1950, which aimed to prohibit atomic weapons, targeted only the nuclear arsenal of the US. On the other hand, the 'struggle for peace' served as a regime-stabilizing means of stirring up fear against an outside enemy. This was especially the case in the new peoples' democracies of the Soviet sphere.

In various resolutions and the FIAPP bulletin published by the Warsaw General Secretariat the organization can be seen to take part in the Soviet campaign. In doing so, the FIAPP established close relations to the WPC, which was the central agency in the Soviet peace campaigns. ${ }^{11}$ This involvement in Cold War politics led to fierce internal conflicts, which escalated in April 1950, when several Western European associations announced their withdrawal from FIAPP. At the same time the Yugoslav Veterans' Union was forced to leave, following the expulsion of Yugoslavs from the Cominform after the split between Tito and Stalin in $1948 .^{12}$

In the summer of 1951, the FIAPP was replaced by the FIR which set up its headquarters in Vienna. Although this was undoubtedly a reaction to the diminished influence of the FIAPP due to the loss of Western members and its reputation as an agent of Soviet communism, the foundation of the FIR has to be seen against the background of the incorporation of resistance veterans and former political prisoners - two groups of survivors initially separated from each other - as according to its statutes resistance veterans had no place within the FIAPP, which officially was an organization exclusively for former

9 La Fédération Internationale des Anciens Prisonniers Politiques du Fascisme (F.I.A.P.P.), n.d. 22508/5, DÖW.

10 Timothy Johnston, 'Peace or Pacifism? The Soviet "Struggle For Peace in All the World", 19481954,' The Slavonic and East European Review 86, no. 2 (2008), 259-282.

11 Rüdiger Schlaga, Die Kommunisten in der Friedensbewegung - erfolglos? Die Politik des Weltfriedensrates im Verhältnis zur Aussenpolitik der Sowjetunion und zu unabhängigen Friedensbewegungen im Westen (1950 - 1979) (Münster/Hamburg: LIT, 1991), 98-100.

12 La Fédération Internationale des Anciens Prisonniers Politiques du Fascisme (F.I.A.P.P.), n.d., 22508/5, DÖW. 
political prisoners. However, the FIR aimed to unite the 'organizations that comprise: a) the partisans, the resistance fighters and all patriots who participated in the victory over fascism; b) the political prisoners, the deportees, the internees and all those persecuted by fascism; c) their surviving dependents'. ${ }^{13}$ It wanted 'to unite its members in peace, as during the wars of liberation' and 'to develop international solidarity among all resistance fighters and victims of Nazism. ${ }^{14}$ Furthermore, the FIR wanted 'to develop international solidarity among all resistance fighters and victims of Nazism', to pursue the struggle for compensation and for the sentencing of war criminals. It further declared its commitment to continuing 'the fight for the defense of democracy and freedom' and to guarding 'against the rebirth of fascism in all its forms'.15 The 'struggle for peace' remained a central issue for the organization.

Like the FIAPP, FIR had members on both sides of the Iron Curtain. An overwhelming majority of representatives were party communists or members of some allied faction, filling high party posts, serving as members of parliament or even acting as vice-ministers. During the 1950s only very few appear to have come from the conservative, liberal or social democratic wing; and even some of those who were not party communists were fellow travelers. ${ }^{16}$ The French hero of the resistance Henri Manhès, who had been FIAPP president since 1950, became president of the renewed organization and led the FIR until his death in 1959. Manhès was born in 1889 and had been a veteran of World War I. He joined the Résistance in 1940. As 'Colonel Frédéric' he became one of its most important leaders. Arrested in March 1943, he was sent to Buchenwald in 1944. In the camp he was a member of the secret resistance. Following liberation, he co-founded the French Fédération Nationale des Déportés et Internés Résistants et Patriotes [FNDIRP; National Federation of Deported and Imprisoned Resistance Fighters and Patriots], one of the most important groups within the FIR, and became president of FNDIRP. Although not a communist, he was a fellow traveler and a member of the left-liberal Parti Radical. Another Frenchman, André Leroy, became General Secretary. ${ }^{17}$ He held this office until 1961. Leroy, born in 1913, had been a member of the

13 Statuten der Internationalen Föderation der Widerstandskämpfer, der Opfer und der Gefangenen des Faschismus, 1951, DY 57/259, Stiftung Archiv Parteien und Massenorganisationen der DDR, Berlin (henceforth: SAPMO).

14 Ibid.

15 Ibid.

16 Informatsionnye materialy o sostave Ispolkoma FIR, 1953, fond 9501, opis 17, file 25, GARF.

17 For Manhès and Leroy cf. Neumann-Thein, Parteidisziplin, 559-61; Wolikow and Vigreux, Les combats, 291-2. Partijnyj Sostav delegacij 12 stran na 2-m kongresse Meždunarodnoj federacii byvšich političeskich zaključennych fašizma, [1947], fond 17, opis 128, dela 24, 
Central Committee of the French Communist Party. Like Manhès he had been a member of the Résistance, was arrested in 1944 and sent to Buchenwald. He succeeded Manhès as president of FNDIRP in 1959. Like many other functionaries of the FIR, Leroy had been previously active in the FIAPP. From the twenty-seven members of the FIR Executive Committee, at least eleven had been members in the FIAPP's leading bodies. Twenty-three of them were party communists - Leroy among them - or members of a satellite party. Even so, the FIR claimed to be above party-lines and striving for 'unity' among the survivors became its most important aim until the mid-196os.

Even before the establishment of the FIR, representatives of associations who had left the FIAPP in $195^{\circ}$ met in The Hague and agreed that a new, non-communist international organization should be founded. The congress in The Hague took place in July 1950, shortly after the Korean War began with the invasion of South Korea by the communist North. In November 1951 the association was formally established and named Fédération Internationale Libre des Déportés et Internés de la Résistance [FILDIR; Free International Federation of Deportees and Resistance Internees]. FILDIR aimed to strengthen civil society and to defend 'democratic freedoms as defined above all in the Universal Declaration of Human Rights'. It also wanted to preserve the memory of 'the victims of suppression and of their fight for freedom.18 While this clearly indicated a Western (non-communist) viewpoint - perhaps including those under communism as 'victims of suppression' - the FILDIR's other aims were not dissimilar to the FIR's; it too wanted to fight for compensation, to support 'solidarity' amongst its members, and pursue international cooperation. ${ }^{19}$

The FILDIR's president was the Belgian Martin Dehousse, who in 1955 was also involved in the foundation of another international survivors' organization, the Union de la Résistance pour une Europe Unie [URPE; Union of Resistance Veterans for a United Europe], which spoke up for a united Western Europe as a bulwark against the Soviet Bloc. However, the real champion of the anti-communist associations was the Belgian socialist and resistance veteran Hubert Halin. In March 1953 he initiated the establishment of the Comité d'Action interallié de la Résistance [CAIR; Inter-Allied Action Committee of the Resistance] in Brussels, which changed its name several

Rossijskij gosudarstvennyj arkhiv social'no-politicheskoj istorii, Moscow; Philippe Robrieux, Histoire intérieure du Parti communiste, (Paris: Fayard, 1980-1986), vol. 4: 708.

Ibid. 
times, eventually being renamed Union Internationale de la Résistance et de la Déportation [UIRD; International Union of Resistance and Deportee Movements] in $1961 .{ }^{20}$ Until his death in 1974 Halin was general secretary of both the UIRD and the URPE as well as the editor-in-chief and sole author of the anti-communist, or in fact, anti-FIR journal La voix internationale de la Résistance. Georges Bidault, then the foreign minister of France, became the UIRD's first president. The UIRD was not an umbrella organization of national survivors' organizations, but rather an association of individuals with Halin in its center. ${ }^{21}$ Unlike the more moderate FILDIR, UIRD and URPE were radically anti-communist. The West German government, who instrumentalized these organizations in Cold War propaganda against East Germany and to weaken the survivors in their struggle for compensation, financed all three anti-communist organizations secretly. ${ }^{22}$ However, this couldn't change the fact that the FILDIR, UIRD and URPE were rather weak organizations, especially when compared with the FIR. Their campaigns did not attract much public attention, and their papers had only a tiny readership and very limited impact. $^{23}$

While neither the FILDIR nor Halin's associations could hide the fact that the survivors' movement, at least on an international level, was predominantly a pro-communist movement - a result of the hostility of fascism and National Socialism towards communism and the strength that communists had within the antifascist resistance during the Second World War - this was not the case in the veterans' movement. In 1950 the World Veterans Federation (WVF) was founded, combining anti-communism with internationalism. The organization was mainly a Franco-American endeavor, with the participation of any Soviet or Eastern European veterans precluded by the invitation of exiles from Poland and Czechoslovakia as well as of the Yugoslav Veterans Union, to which

20 To make the text more reader-friendly, the CAIR is referred to throughout as UIRD, regardless of its name in the time analyzed. Hubert Halin, L'Europe unie: Objectif majeur de la Résistance (Paris/Bruxelles: Editions de l'URPE, [1968]), 66.

21 Pieter Lagrou, The legacy of Nazi occupation: Patriotic memory and national recovery in Western Europe, 1945-1965 (Cambridge/New York/Melbourne: Cambridge University Press, 2000), 282.

22 Jascha März, Zwischen Politik und Interessenvertretung: Die Verbände der politischen Opfer des Nationalsozialismus in der Bundesrepublik Deutschland von 1947 bis 1990 (PhD diss., Köln, 2016), 187-188, 232.

23 Henning Fauser, “Indignez-vous!” Zur Empörung in den Äußerungen französischer KZ-Überlebender', in Brücken bauen - Kulturwissenschaft aus interkultureller und multidisziplinärer Perspektive: Festschrift für Dorothee Röseberg zum 65. Geburtstag, ed. Marie-Therese Mäder et al. (Bielefeld: Transcript, 2016), 312. 
the FIAPP had broken off all contact in $1950 .{ }^{24}$ As with the foundation of the FILDIR, its immediate context was the beginning of the Korean War and the communist 'peace campaigns', against which FILDIR and WVF positioned 'peace' as inextricably linked with 'freedom'. ${ }^{25}$ Like the UN, it aimed at an utopian vision of 'world peace', in which conflicts were solved solely by negotiations and every women and man could live in joy. ${ }^{26}$

\section{Resistance Myths}

The basis of the FIR's resistance myth was laid down at its congress in Vienna in 1951, when many of the delegates who took the floor recounted the history of occupation and resistance in their home countries. Thus, the statements made by speakers reflected the conceptions of history that their sending organizations had adopted and were linked to national memories. These propagated a heroic image of the war, in which each nation's own resistance fighters and soldiers were glorified, while the collaboration of large sections of the population was denied, reduced to selected figures and concealed beneath a myth of unity of the resistance fighters and the whole people against the German enemy. ${ }^{27}$

However, despite the fact that the speakers represented countries ranging from Norway to Italy, from Russia to France, the discourse focused on similar motifs. In the FIR, elements of national memories coalesced to form a unified FIR version of events, a common memory which ultimately welded national and transnational elements together. During the 1950s and early 196os, speakers at congresses and meetings as well as official papers and publications of the FIR all used the same keywords, such as freedom, democracy or national independence, which the resistance had aimed to restore. Strong emphasis was put on the 'patriotism' of the resistance members - their love of their homeland

24 Ángel Alcalde, 'The World Veterans Federation: Cold War politics and globalization,' in War Veterans and the World after 1945: Cold War Politics, Decolonization, Memory, ed. Ángel Alcalde and Xosé M. Núñez (New York: Routledge, 2018), 33-49.

25 F.I.L.D.I.R. Fédération Internationale Libre des Déportes et Internés de la Résistance. Statuts Déportation et Liberté (1953) no 1, 21-22.

26 Julia Kling, 'Dreaming an Unlimited Dream in a World of Division: A Veterans' Utopia?' Erinnerungskulturen Weblog, 17 June 2015 (updated 28 March 2019), https://erinnerung. hypotheses.org/276\#more-276, accessed November 5, 2020.

27 Cf. i.a.: Jörg Echternkamp and Stefan Martens, ed., Experience and Memory: The Second World War in Europe (New York: Berghahn, 2010); Richard N. Lebow, Wulf Kansteiner and Claudio Fogu, ed., The Politics of Memory in Postwar Europe (Durham / London: Duke Univ. 
being the only motivation for fighting the occupying powers, a belief also held by both left-wingers and nationalists outside the survivors' milieu. ${ }^{28}$

All of the above-mentioned terms had different meanings depending on their context; they were part of general Western discourse as well as of communist language and Soviet propaganda. In the latter context, 'patriotism' and 'national independence' meant love of the socialist home country, and the 'freedom' to choose the socialist path and a 'democracy' of the people - in more forthright terms, the dictatorship of the Communist Party. ${ }^{29}$ In this ambiguous way the congress of 1951 declared that the aim pursued with the establishment of the FIR was 'to defend ... the independence of our respective fatherlands, the democratic freedoms and peace.' 30 'International solidarity', another key element, referred to the idea of international cooperation as laid down in the UN Charter, but also to the internationalism of the workers' movement. ${ }^{31}$

The most important term in the 1950s was 'unity', which could be found in almost every speech and paper of the FIR at that time. 'Unity' basically meant two things: The common struggle against 'fascism' in which everybody took part regardless of gender, political or religious belief until the victory was won in 1945, and the community of all survivors - or as the FIR would put it - of all 'resistance fighters' after 1945. Despite the term actually deriving from a communist context and meaning the alliance of all antifascist forces, the myth of unity was also part of a non-communist memory. ${ }^{32}$

The FIR never defined any of these terms. Given the involvement of its representatives in communist politics, anti-communists assumed that it wanted to disguise its real purpose as a communist front organization. ${ }^{33}$ However, it seems likely, during the Cold War, that it wanted people to understand them as they liked, thus helping to bridge the gap between East and West. The same can

Press, 2006); Jan-Werner Müller, ed., Memory and Power in Post-War Europe: Studies in the Presence of the Past (Cambridge: Univ. Press, 2002).

28 Simon Kitson, 'Creating "a Nation of Resisters"? Improving French Self-image, 1944-6,' in The Lasting War: Society and Identity in Britain, France and Germany after 1945, ed. Monica Riera and Gavin Schaffer (Basingstoke: Palgrave Macmillan, 2008), 80.

29 László Révész, Die Sprache als Waffe: Zur Terminologie des Marxismus-Leninismus (München: Hanns-Seidel-Stiftung, 1983).

30 Manifest des Internationalen Vereinigungskongresses, July 3, 1951, DY 57/259a, SAPMO.

31 Jussi M. Hanhimäki, The United Nations: A very Short Introduction (Oxford: Oxford Univ. Press, 2008); Reiner Tosstorff, Profintern: Die Rote Gewerkschaftsinternationale 1920-1937 (Paderborn: Schöningh, 2004).

32 http://www.unadifffr/presentation_unadif_fndir.pdf, accessed May 5, 2017. The website is offline since the end of 2017).

33 E.g. Alexander Heldring, The International Federation of Resistance Movements: History and Background (The Hague: INTERDOC, 1969). 
be said of the memory created by the FIR, as it picked up elements of memory which all narratives had in common. The FIR's resistance myth was very similar to that of the anti-communist survivors, something that can be illustrated by the use of the terms 'heroes' and 'martyrs', which were used all over Europe for the resistance fighters and part of communist and non-communist contexts. In both cases the resistance fighters were presented as spotless 'heroes' and noble 'martyrs' to the cause. ${ }^{34}$

On 30 June 1951, Manhès opened the congress with a programmatic address, in which he outlined important parts of the narrative and the self-understanding of the FIR. The motives of heroism and martyrdom, unity, patriotism and international solidarity played a central role in Manhès' speech. A goal for the establishment of the FIR was, Manhès stated, to resurrect 'the most beautiful unit, which was born during the heroic days of the resistance fights' and because the reference to the present was elementary in the speech and for the narrative - to prevent a new war. ${ }^{35}$ Manhès addressed the representatives of the resistance fighters from nineteen European countries gathered in Vienna as the 'dearest and purest, whom our homeland possesses' and expressed thereby the attitude of most of the assembled delegates as belonging to an elite, ${ }^{36}$ distinguished by their common experience of active combat against Nazism. Ordinary people were allowed a merely subsidiary role. ${ }^{37}$ They were the 'most fervent patriots' and at the same time the representatives of 'our dead: those who were shot, beheaded, guillotined, hanged and tortured, women and men who were thrown into the prisons, deported because they had the courage to say NO to the fascist intruder'.38 Manhès thus integrated not only armed resistance, but all forms of resistance. The FIR, which was be established at the congress, should be a living being and 'an international monument', which would act for the glory of the dead. This monument will ensure that the 'ideas of peace and freedom' are preserved and will contribute to defend the 'free people' against those 'who have adventurous plans'. It will be a 'weapon against

34 Susan Hogervorst, Onwrikbare herinnering: Herinneringsculturen van Ravensbrück in Europa, 1945-2010 (Hilversum: Verloren, 2010), 267; Lagrou, Legacy, 211-212.

35 Internationaler Kongress der Widerstandskämpfer und Opfer des Faschismus. Eröffnungsrede [Manhès], June 30, 1951, 1841/2/151, Archiwum Akt Nowych, Warsaw, (henceforth: AAN).

36 Ibid.

37 Ralf Kessler and Hartmut R. Peter, 'Antifaschisten in der sBz: Zwischen elitärem Selbstverständnis und politischer Instrumentalisierung,' Vierteljahrshefte für Zeitgeschichte 43 (1995); Kitson, 'Creating “a Nation of Resisters"?' 67-85, 76-77.

38 Internationaler Kongress der Widerstandskämpfer und Opfer des Faschismus. Eröffnungsrede [Manhès], June 30, 1951, 1841/2/151, AAN. 
... the war', with which Manhès announced the participation of the FIR in the 'struggle for peace'. 39 The goals of the resistance before 1945 - national independence, liberty and peace - 'are also today still the reasons for our fight', Manhès continued.

'When our countries were invaded and occupied by the enemy hordes, it was in a momentum of courageous patriots that the resistance movement was born and the resistance movement became international. ${ }^{40}$ Manhès thus ignored the difficult beginnings of the resistance, which only became effective from $1943 / 44 .{ }^{41}$ At the same time he overemphasized the international connections of the resistance, which was nevertheless central to the self-understanding of the FIR as an international organization that claimed direct descendance from the resistance: ${ }^{42}$ The concept of a pan-European resistance was a fundamental element of its narrative. That applied also to the memory of the concentration camps, which had been characterized more by 'solidarity, friendship, brotherliness' than by 'misery, suffering and egoism. ${ }^{43}$ Only this close international and cross-class cooperation of concentration camp prisoners of different nations enabled them to resist the Nazis. The 'common' experience welded resistance fighters and former prisoners together. ${ }^{44}$

The resistance was usually presented as a comprehensive mass movement with participants from all walks and philosophies of life, religion, denomination and parties. 'In all countries they came from all sides: from East to West, from North to South, workers and intellectuals, believers and atheists, inhabitants of cities and countryside', as Manhès put it. ${ }^{45}$ This all-embracing myth was not only propagated by the FIR, but also by the state-sponsored memory cultures of the communist regimes as well as, for example, by the Gaullist resistance myth and other non-communist memories in the West. ${ }^{46}$ The resistance

39 Ibid.

40 Ibid.

41 Mark Mazower, Hitlers Imperium (München: Beck, 2009).

42 Ulrich Schneider, 'Zur Geschichte der Internationalen Föderation der Widerstandskämpfer (FIR),' Informationen: Wissenschaftliche Zeitschrift des Studienkreises Deutscher Widerstand 1933-1945 31, no. 63 (2006): 26-27.

43 Internationaler Kongress der Widerstandskämpfer und Opfer des Faschismus. Eröffnungsrede [Manhès], June 3o, 1951, 1841/2/151, AAN.

44 E.g. Information für das Sekretariat des ZK der SED, 24.o9.1982, DY 30/626o, SAPMO.

45 Internationaler Kongress der Widerstandskämpfer und Opfer des Faschismus. Eröffnungsrede [Manhès], June 30, 1951, 1841/2/151, AAN.

46 Henry Rousso, The Vichy syndrome: History and memory in France since 1944 (Cambridge, MA: Harvard University Press, 1991); Arnd Bauerkämper, Das umstrittene Gedächtnis: Die Erinnerung an Nationalsozialismus, Faschismus und Krieg in Europa seit 1945 (Paderborn: Schöningh, 2012). 
fighters were seen as a huge, harmonious family of antifascists, united against the common enemy and fighting for the same aims, and as a mass movement in which both men and women took part. The ideological conflicts and civil wars between different partisan groups were completely denied.

Similar to the Gaullist memory, which tried to cover up the cracks between the different, party-affiliated resistance groups in France, ${ }^{47}$ parties never played a role in the resistance myth of the FIR - the FIR understood itself as strictly non-partisan. Thus their narrative differed from the communist master narrative, in which the Communist Party was assigned the leading role, the Party leadership - which was in exile in Moscow during the war - commanding the resistance, a fairytale told not only in the East, but also in France. ${ }^{48} \mathrm{Up}$ until the de-Stalinization, Stalin had the role as genius and charismatic leader of the resistance - the FIR did not take over that either.

A further element of the resistance myth of the FIR was the military meaning of the resistance. While Western resistance veterans - both communist and non-communist - could self-consciously present themselves as the liberators of their home countries, their comrades from Poland and Czechoslovakia were forced to see themselves as an auxiliary force of the victorious Soviet Army ${ }^{49}$ which had - as Stanisław Kiryluk, in 1951 the incumbent chairman of the Polish Związek Bojowników o Wolność i Demokracje [ZBoWiD; Union of Fighters for Freedom and Democracy] put it at the congress in Vienna - 'brought freedom' to their people. ${ }^{50}$

In a political climate where communist resistance veterans had lost much of their influence, this self-affirmation cannot be called hubristic; it was more a reaction to the marginalization of the resistance in politics and society all over Europe, ${ }^{51}$ as the alliances between communists, socialists and conservatives from during the War were disbanded. In France and Italy several thousand former partisans faced criminal prosecution for alleged crimes before and after liberation. ${ }^{52}$

47 Rousso, Vichy syndrome, 16-18.

48 Kitson, 'Creating “a Nation of Resisters"?' 77.

49 Natali Stegmann, Kriegsdeutungen, Staatsgründungen, Sozialpolitik: Der Helden- und Opferdiskurs in der Tschechoslowakei 1918-1948 (München: Oldenbourg, 2010), 268.

$5^{\circ}$ Stenographisches Protokoll des Internationalen Kongresses der Widerstandsbewegung und der Opfer des Faschismus, June 30 - July 3, 1951, fond 1841/2, file 150, AAN.

$5^{1} \quad$ Tony Judt, Die Geschichte Europas seit dem Zweiten Weltkrieg (Bonn: bpb, 2006), 85-86.

$5^{2}$ Fabrice Grenard, 'La Résistance en accusation: Les procès d'anciens FFI et FTP en France dans les années d'après-guerre,' Vingtième Siècle, no. 130 (2016); Michela Ponzani, 'Trials of Partisans in the Italian Republic: The Consequences of the Elections of 18 April 1948,' Modern Italy 16, no. 2 (2011): 121-138. 
At the same time, the Eastern 'people's democracies' were torn apart by the Stalinist purges. The survivors were predetermined to become victims, as suspicion fell on them because of their resistance activities and because, during their imprisonment in German camps or participation in the Spanish Civil War, they had had contacts with Westerners. As a result, resistance veterans lost their places in governments, were thrown into prison or, as in the case of former Buchenwald prisoner Josef Frank, were executed. ${ }^{53}$ The associations were transformed into institutions that stayed loyal to government but had only marginal influence. ${ }^{54}$ This pattern of developments can also be seen in Tito's Yugoslavia. ${ }^{55}$

Central experiences of the survivors were not expressed; they did not become part of the memory of the FIR. Much of what the survivors had experienced was not memorable, at least not within the framework of the FIR, which was dominated by the communist politics of memory and had to serve above all political interests in the Cold War. These included, for example, the isolation of the resistance and the double-edged nature of its actions, which often triggered retaliation by the Germans, from which the civilian population suffered. These victims functioned in the discourse of the FIR, in alignment with communist discourse, only as proof of the cruelty of the National Socialists. ${ }^{56}$ The complicated reality of the occupation, during which most people were at best indifferent toward the partisans, was reduced to an extreme simplification as were the stories of resistance in the concentration camps, in which all prisoners were in solidarity with each other and resisted against the ss, while the brutality of the prisoner society in the concentration camps, powerlessness against the ss, and the role of the prisoner functionaries in the camps as 'assistants' of the ss were ignored. ${ }^{57}$

The memory of fate of women in the resistance and in the camps was also eclipsed in the male-dominated FIR and in the patriarchally shaped social climate, remaining largely buried until the end of the 196os. ${ }^{58}$ Even

53 Neumann-Thein, Parteidisziplin, 192.

54 Stengel, Hermann Langbein, 118-119.

55 Dušan Nečak, 'Dachauski procesi 1947-1949,' Kronika 57 (2009).

56 Stengel, Hermann Langbein, 100.

57 Cf. i.a. István Deák, Europe on Trial: The Story of Collaboration, Resistance, and Retribution During World War II (Philadelphia, Pa: Westview Press, 2015); Nikolaus Wachsmann, KL: Die Geschichte der nationalsozialistischen Konzentrationslager (Bonn: Bundeszentrale für politische Bildung, 2016).

58 Rebecca Clifford, Robert Gildea, and Anette Warring, 'Gender and sexuality', in Europe's 1968: Voices of revolt, ed. Robert Gildea et al. (Oxford, NY: Oxford University Press, 2017), 239-257. 
survivor federations, in which the members were exclusively women, such as the amicales of Ravensbrück or the French Association Nationale des Anciennes Déportées et Internées de la Résistance [ADIR] cultivated a memory, in which the heroic resistance stood in the center. ${ }^{59}$ Specifically female prison experiences, such as the camp brothels, to which only privileged male prisoners, usually prisoner functionaries, had access and in which women were subject to forced sex work, were only occasionally remembered. ${ }^{60}$

\section{Resistance Veterans and Holocaust Survivors}

Although armed resistance was emphasized, the FIR understood 'resistance' in a broad sense and included passive resistance, sabotage and other forms of opposition. Survivors of the concentration camps including the Jews were counted, since they were all seen as having been captured exclusively for defying the Germans. ${ }^{61}$ They were seen as part of the 'family of antifascists'. The memory of the FIR denied all differences; 'the Socialist and the Catholic, the Jew and the Communist' had all suffered the same fate, as the French Resistance veteran Charles Fournier-Bocquet put it. ${ }^{62}$ Indeed, the victims of Nazism were remembered exclusively and indiscriminately under the label 'resistance fighter'. The Jewish experience was therefore integrated into the antifascist memory maintained by the FIR and other organizations of the political left, but they were rarely mentioned explicitly and the singularity of the Holocaust was not acknowledged. The memory of the left-wing associations was far more inclusive than that of anti-communist or nationalist organizations. Especially during the antisemitic campaign of the late Stalin years and their immediate aftermath, the memory of the Jewish victims was almost completely erased. ${ }^{63}$ This (amongst other omissions) was reflected at the congress in Vienna where there was a complete absence of any reference to the Holocaust. When a delegation from the FIR visited Auschwitz in January 1955, the only nod the

59 Henning Fischer, Überlebende als Akteurinnen: Die Frauen der Lagergemeinschaften Ravensbrück. Biografische Erfahrung und politisches Handeln, 1945 bis 1989 (Konstanz/ München: UVK, 2018); Debra Workman, Refusing the Unacceptable: The Women of the 'Association nationale des anciennes déportées et internées de la Résistance (ADIR)' (Ann Arbor, MI: UMI, 2007).

6o Frauen-Konzentrationslager Ravensbrück: Geschildert von Ravensbrücker Häftlingen (Wien: Stern, 1945).

61 Ibid.

62 Stenographisches Protokoll des Internationalen Kongresses der Widerstandsbewegung und der Opfer des Faschismus, June 30 - July 3, 1951, fond 1841/2, file 15o, AAN.

63 Renata Kobylarz, Walka o pamięć: Polityczne aspekty obchodów rocznicy powstania w getcie warszawskim 1944-1989 (Warszawa: Instytut Pamięci Narodowej, Komisja Ścigania Zbrodni przeciwko Narodowi Polskiemu, 2009), 93-100. 
organization's journal made to the mostly Jewish victims who had died there was to publish a picture of the 'memorial to the Jewish martyrs', which stood at the end of the 'ramp' at Birkenau. ${ }^{64}$ In the late 1940s, and again in the second half of the 1950s, the FIAPP and the FIR protested against West German antisemitism, ${ }^{65}$ but they said nothing about the Stalinist antisemitism of the early 195 os and the campaign against 'rootless cosmopolitan', during which prominent members of the Jewish Anti-Fascist Committee were shot. ${ }^{66}$

The nationalist survivors' associations fostered far more exclusive policies. Here there was often no space for Jews or concentration camp prisoners at all. Only the heroes of the resistance were recognized, not the deportees. These associations tended to ignore postwar antisemitism, and they cultivated their own anti-Jewish resentments. In contrast to their left-aligned counterparts, they often associated 'Jew' with 'communist', thus continuing the right-wing propaganda Goebbels had promulgated. ${ }^{67}$ Although a similar stance could be found in organizations which were FILDIR members, the FILDIR itself declared that 'the twentieth century saw political oppression, oppression of race and religion' emphasizing the 'heroic dead' of 'millions of men, women and children for the defense of liberty and democracy'. 68

Despite the antisemitism among left-wingers, some Jewish survivors welcomed the inclusive antifascist narrative. It helped them gain social recognition and reintegration into a society that had often been indifferent towards their fate, in which antisemitism was still widespread, and which might be hostile to Jewish returnees who demanded their 'Aryanized' property back. ${ }^{69}$ Jews were attracted to this inclusive narrative on legal grounds as well, since resistance fighters received significantly better pensions than 'passive' victims. ${ }^{70}$

The majority of non-Jews had no interest in remembering the Jewish victims, a recollection which would have brought the 'dark' sides of the occupation and the moral responsibility of the majority back to mind, along with

64 '10. Jahrestag der Befreiung von Auschwitz,' Der Widerstandskämpfer 3, no. 1 (1955): 16.

65 “'Oliver Twist" - a Film of Anti-Semite Character', FIAPP-Informations, March 26 1949; 'Antisemitismus, eine Begleiterscheinung der Aufrüstung in der Deutschen Bundesrepublik,' Der Widerstandskämpfer 6, 2/3 (1959).

66 Gennadi Kostyrchenko, Out of the Red Shadows: Anti-Semitism in Stalin's Russia (New York: Prometheus Books, 1995).

67 Lagrou, Legacy.

68 'Compte rendu du 2e Congrès de la F.I.L.D.I.R.: Rome $2-5$ octobre 1952.' Déportation et Liberté, no. 1 (1953), 3-7.

69 David Bankier, ed., The Jews are Coming Back: The Return of the Jews to their Countries of Origin after WW II (Jerusalem: Berghahn Books, 2005).

70 Lagrou, Legacy. 
the ignorance of many towards the fate of the Jews during the Holocaust and shameful acts of collaboration. ${ }^{71}$ Furthermore, as a genuinely transnational event, the Holocaust did not fit into the dominating national narratives and the Jewish victims were often foreign refugees who had sought refuge in countries that were later occupied by the Germans. It was to be a long process, a dawning of consciousness, beginning at the end of the 1950s and lasting until the 199os, surfaced until the Holocaust was fully recognized and became a central part of war memory.

\section{Different Understandings of 'Fascism' and 'Resistance'}

Conflicts between communist and non-communist survivors cropped up when their talk turned to 'fascism'. In the FIR, 'fascism' was used as a substitute for National Socialism, a term which was almost completely avoided. The terms 'fascist' and 'fascism' were also used in a different sense, referring to current developments in the West (although it was sometimes unclear which 'fascism' was meant). From 1948, the main target of the 'antifascist' propaganda of the FIAPP was the United States, which was accused of everything possible, from aiding and abetting National Socialists in West Germany to 'warmongering.'72 However, enemies termed 'fascist' could be replaced by others, and from the beginning of the 1950s, the focus began to shift to West Germany.

Closely related was the concept of 'resistance'. This too had shifting meanings. It meant having fought the Nazi German occupiers in the past, but it also stood for combatting 'fascism in all of its forms' in the postwar settlement. ${ }^{73}$ An exhibition presented at the 1951 congress in Vienna emphasized this understanding. Documents and pictures in the first section dealt with the past - the rise of right-wing extremism in the interwar period, and the successes of the resistance against German occupation and National Socialism. A second section addressed the postwar era. It traced the rise of neo-fascist groups and the spread of Nazi ideology after 1945. Again, it could demonstrate an 'increasing resistance movement' against these developments. ${ }^{74}$ There was an essential focus on protests against 'war preparations and warmongering', profiling the value and effectiveness of the survivors' organizations in the 'struggle for peace'. Viewed together, the two parts of the exhibition implied a continuity of resistance - as the FIR understood it - from wartime to the present day.

71 Confino, Remembering.

72 La Fédération Internationale des Anciens Prisonniers Politiques du Fascisme (F.I.A.P.P.), n.d., 22508/5, DÖW 22508/5.

73 Statuten der Internationalen Föderation der Widerstandskämpfer, 1951, DY 57/259, SAPMO.

74 'Unsere Kongreßausstellung,' Der neue Mahnruf 4, 7/8 (1951): 9. 
In their understanding of 'fascism' and 'resistance', a deep gap opened up between the non-communist survivors, who associated 'fascism' with any totalitarian regime, including communist ones. The West German FILDIR member Bund der Verfolgten des Naziregimes [BVN; Association of Persecutees of the Nazi Regime] declared: 'Violence - terror - dictatorship! It is necessary to resist against it, today just as yesterday. Yesterday against the brown - today against the red tyrants. 75 The FIR condemned this 'policy hostile to the Soviets' and identified it with the outlook of Hitler. ${ }^{76}$

\section{Antifascist Protests in the 1950s}

The campaigns of the 1950s instrumentalized memory to sway politics and propaganda. For the FIR and the pro-communist survivors' organizations, the most important field of protest was concerned with West German rearmament. This had been under negotiation since the autumn of 1950, occasioned by the communist incursion into South Korea on June 25 of that year. The invasion had been supported by Stalin, and fears of Soviet aggression were growing in the West. In late October 1950, picking up on a proposal made by Winston Churchill (then Opposition leader in the United Kingdom), the French foreign minister René Pleven suggested forming a European army, which would include newly deployed German units. Following Pleven's speech, negotiations took place between France, Italy, the Benelux countries and West Germany, leading to the treaty, signed in May 1952, which established the European Defence Community (EDC). ${ }^{77}$

A heated debate surrounded the issue of West German rearmament, brewing in the late 1940s, and continuing well into the second half of the 1950s. It aroused strong feelings in Western societies and sparked major protests throughout Western Europe. ${ }^{78}$ Opponents stepped forward from every political camp, and resistance veterans of all political convictions were at the

75 Bund der Verfolgten des Naziregimes (BVN), ed., Widerstand: Gestern und Heute, n.p. [1950], 20.

76 Konferenz des Exekutivkomitees der F.I.R.: Die Feier des X. Jahrestages der Befreiungskämpfe und der Internationale Kongress der Widerstandskämpfer. Bericht des Generalsekretärs der FIR André Leroy, February 26-28, 1954, 1841/2/41, AAN.

77 Lutz Köllner et al., ed., Anfänge westdeutscher Sicherheitspolitik 1945-1956, vol. 2: Die EVGPhase (München: Oldenbourg, 1990).

78 Holger Nehring, Politics of Security: British and West German Protest Movements and the Early Cold War, 1945-1970 (Oxford: Oxford Univ. Press, 2013). 
forefront of the protests. Despite their different motives, they all shared a deep distrust of Germany. Only a few resistance veterans, like Simone Veil, who had survived Ravensbrück, Auschwitz, and Bergen-Belsen, spoke out openly in favor of a new West German army. ${ }^{79}$ After the French National Assembly rejected the EDC treaty in August 1954, the Paris Accords were signed at the London and Paris conferences of September and October 1954, which allowed the admission of West Germany into NATO and permitted it to deploy an army. In December 1954 the treaties passed the French National Assembly. After the ratification process was completed, they came into force in May 1955, ten years after the end of the War.

The FI R maintained that 'remilitarization', as it was constantly called, would lead to the re-emergence of the old German militarism. The sentiment and the term were by no means confined to communist milieus. ${ }^{80}$ There were widespread fears that the proposed new European army would quickly fall under German command, as there were so many well-trained former Wehrmacht officers around. Since the horrors of German occupation during the Second World War had left deep scars in the collective memory, this was seen as a very real threat. ${ }^{81}$ Also, the German invasion of France and Belgium in World War One was sufficiently recent to have remained vivid in many people's recollections. ${ }^{82}$

Furthermore, the FIR called rearming West Germany 'treachery' - a betrayal of the 'achievements and values' of the resistance, which had fought against foreign occupation and for national independence, freedom and peace. These would be threatened, as the new German army would seek revenge and attack its neighbors in order to regain the lost German territories in the East and in the West. ${ }^{83}$ As Konrad Adenauer's government never recognized the new border to Poland and Czechoslovakia as well as the transfer of smaller German territories to Belgian, the Netherlands and Luxemburg, this argument seemed plausible.

These nationalist arguments fitted well into the rhetoric of communist parties, as to stand up for national sovereignty promised to appeal to more

79 Simone Veil, Und dennoch leben: Die Autobiographie der großen Europäerin (Berlin: Aufbau, 2009), 126-127.

8o Judt, Geschichte, 935-936.

81 Linda Risso, Divided We Stand: The French and Italian Political Parties and the Rearmament of West Germany, 1949-1955 (Newcastle: Cambridge Scholars Pub., 2007), 169-170.

82 Lagrou, Legacy, 295-298.

83 Tagung des Büros der F.I.R.: Die Aufgaben der FIR nach ihrem II. Kongress, January 23-24, $1955,1841 / 2 / 45$, AAN. 
people. ${ }^{84}$ For the FIR, it is likely that it tried to attract survivors of all stripes including nationalists. The consequence of such rhetoric emphasizing national sovereignty hindered the establishment of a real transnational community of survivors and the emergence of a transnational memory.

Stalin's death in March 1953 had no obvious effect on the FIR, as it never made reference to the Soviet dictator. The campaign against rearmament continued and reached its climax in 1954/55, when the tenth anniversary of the liberation was celebrated throughout Europe. ${ }^{85}$ The commemorations offered an ideal opportunity for protests, as participant numbers and media attention would both be high. As a result of the thaw and common protests against German rearmament, representatives of anti-communist associations also joined in the commemorations, sometimes taking the floor and demanding an end to the political split between the survivors. ${ }^{86}$ For a short while it seemed as though the FIR would come close to restoring the mythic 'unity'.

The most important event the FIR sponsored was an 'International Festival Week of the Resistance', held in Vienna in November 1954, only four weeks after the fateful decision made in Paris. There was an art exhibition containing works by artists who had been engaged in the resistance, and models of various memorials. ${ }^{87} \mathrm{~A}$ book fair displayed more than 1,300 titles of novels, nonfiction books and poetry;8 and a historical exhibition, which was organized into national sections, explained the history of the resistance from past to present in fifteen countries. ${ }^{89}$ Although the Austrian authorities and the non-communist media largely ignored the festival, ${ }^{90}$ several thousand people came to visit the exhibitions in only two weeks. However, the real crowd-puller was a movie festival, where films about the resistance and the concentration camps were shown. Among them were such famous films as Wanda Jakubowska's drama The Last Stage (1947) dealing with the women's camp at Birkenau or

84 Risso, Divided, 171-174.

85 Maximilian Becker, “Keine Waffen für unsere Henker": Ehemalige Verfolgte des Ns-Regimes und die westdeutsche Wiederbewaffnung,' Vierteljahrshefte für Zeitgeschichte 66 (2018): 87116, https://doi.org/10.1515/vfzg-2018-0oo4.

86 'Eindrucksvolle Manifestation des europäischen Widerstands: Delegationen aus Frankreich, Österreich, Belgien, Holland, Italien und der DDR,' Die Tat 6, no. 20 (1955), 4-5.

87 Rino dal Sasso, 'Die erste internationale Kunstausstellung der Widerstandsbewegung,' Der Widerstandskämpfer 2, no. 6 (1954).

88 Tagung des Büros der F.I.R., Die Aufgaben der FIR nach ihrem II. Kongress, January 23 - 24, $1955,1841 / 2 / 45$, AAN.

89 'Eine Ausstellung über die Geschichte des europäischen Widerstandskampfes,' Der Widerstandskämpfer 2, no. 6 (1954).

90 'Die Regierung und das Internationale Treffen der Widerstandskämpfer', Der neue Mahnruf 6, no. 12 (1954). 
René Clément's The Battle of the Rails (1946). Both films had a documentary approach and endeavored to authentically present their topics, although it was clear that they were fiction. They could therefore combine the left-wing memory with a more conservative one, as the pictures presented and the stories told were part of a common narrative of the camps and the War. The Battle of the Rails told the history of French railway workers, whose resistance stretched from smuggling letters to sabotage. Completely ignoring the essential participation of the French railway in the deportation of the Jews and the collaboration of its management, the film sportrayed resistance as motivated exclusively by national motives, claiming it to be a collective effort of all French people, and as a decisive contribution to liberation.

At the same time, they developed these memories and the resistance narrative propagated by the FIR: The Last Stage made it clear, for example, that above all Jews were gassed in Auschwitz. Other movies served without a doubt the communist narrative, for example, the Soviet film Zoja about Zoja Kosmodem'janskaja, who was executed as a partisan in 1942 by the Germans. Kosmodem'janskaja was presented as a heroine with exemplary character, but the film also exerted a poetic power and was nominated at the Cannes Film Festival of 1946, where finally The Battle of the Rails received the award. Its overwhelming success made the International Festival at Vienna a model for similar ones organized by national survivors' organizations in several countries both in the East and the West. ${ }^{91}$

The stated goal of these exhibitions and film festivals was to acquaint the public with the 'struggles of the resistance movement' in countries not their own and to facilitate international contacts between artists, writers and survivors in order to raise debate and create a common memory, emphasizing the national character of the resistance movement as well as its cross-border and international alliances. ${ }^{92}$

The festival centered around a congress attended by over seven hundred delegates from all over Europe. Politically, the most important outcome from this was a manifesto paying tribute to the resistance and the liberation of Europe ten years earlier and condemning 'the rearmament of Germany' as 'a betrayal of the resistance; the resuscitation of Hitler's demon'.93 During

91 Tagung des Büros der F.I.R., Die Aufgaben der FIR nach ihrem II. Kongress, January 23 - 24, $1955,1841 / 2 / 45$, AAN.

92 Aktionsprogramm der Internationalen Föderation der Widerstandskämpfer, November 28, $1954,1841 / 2 / 42$, AAN.

93 'Manifest des Internationalen Treffens und der Festwoche der Widerstandsbewegung,' Der neue Mahnruf 7, no. 12 (1954). 
the congress there had been intense disputes about the wording. While the original proposal which was prepared by the FIR had only words of complete condemnation for the Paris Treaties and West German rearmament, for some Gaullist delegates from France this was unacceptable. ${ }^{94}$ In the end, the manifesto was passed by the meeting almost unanimously, only four delegates abstained. Well known non-communists put their signatures to it - including Robert Scholl, the father of Hans and Sophie Scholl; Ferruccio Parri, the former Italian prime minister and chairman of the Catholic Italian Federation of Partisans' Associations; and Édouard Herriot, who had been prime minister of France on three different occasions and was one of the architects France's early left-wing coalition movements during the 1920s, the Cartels des gauches.

\section{The Year 1956 and its Consequences}

The commemorations of 1954/55 also saw a change in the tone of the FIR's statements and publications, a move away from the aggressive, anti-imperialist rhetoric of the Stalin era with its name-calling of 'warmongers. ${ }^{95}$ Suddenly such terms almost completely disappeared, and the condemnation of the US decreased to become only a minor theme.

This was after the coming of détente. In March 1953, Russian Prime Minister Georgy Malenkov declared a policy of 'peaceful coexistence' as a new guideline for Soviet foreign policy. In May 1955 the two nuclear superpowers signed the Austrian state treaty, and, in July, met at the Geneva summit. ${ }^{96}$ For the FIR another consideration was that instead of further attacking the US, keeping the focus on West Germany would extend its influence among survivors, as the common distrust against rearming the FRG was still strong.

Thus, a kind of 'linguistic destalinization' had already begun within the FIR when, in February 1956, Nikita Khrushchev made his 'secret speech', condemning the personality cult around Stalin and (inter alia) criticizing Stalin's decisions before and during the German-Soviet war of 1941-45, which had led to

94 Don Cook, 'After Resistance Fighters: wvF's Annual Talks Start in Vienna Today,' New York Herald Tribune: European Edition, November 29, 1954.

95 E.g. Konferenz des Exekutivkomitees der F.I.R., Die Feier des X. Jahrestages der Befreiungskämpfe und der Internationale Kongress der Widerstandskämpfer. Bericht des Generalsekretärs der FIR André Leroy, February 26 - 28, 1954, 1841/2/41, AAN.

96 Judt, Geschichte, 280-281. 
heavy Russian losses. ${ }^{97}$ Although this speech ended the cult of Stalin within the communist consciousness and changed the Soviet war memory by expelling Stalin from its pantheon, ${ }^{98}$ it barely affected the FIR for whom Stalin had played no role in its resistance myth. The text of the 'secret speech' spread rapidly and quickly became known in the FIR's Vienna office, where it was a matter of private talks. ${ }^{99}$ However, along with other Soviet changes, like the dissolution of the Cominform in April 1956, Khrushchev's speech caused major cracks within the Communist Movement. These led to the workers' demonstrations in Poznań in June 1956 and to the Hungarian Revolution in late October. ${ }^{100}$

In the summer of 1956, a further thawing could be felt. The FIR intensified its contacts with non-aligned organizations and opened dialogue with its critics, such as the radically anti-communist CAIR, to restore 'unity' among the survivors. Furthermore, the FIR opened up contacts to WVF. Its underlying concern seemed to be less about communist ideology than a hope that détente could heal divisions among the survivors. Its wider aims remained somewhat unclear, and it never formally distanced itself from Stalinism or condemned the persecution of Nazi victims and resistance fighters in Eastern Europe after the war. ${ }^{101}$

The FIR's conduct during and after the Hungarian Uprising soon put an end to any rapprochement, as it never condemned the Soviet invasion, or protested against the harsh penalties the Soviet and Hungarian courts imposed on participants in the Uprising, even though former resistance veterans were among the convicted. ${ }^{102}$

It was left to the FILDIR to send a letter to the UN Secretary-General protesting against 'the totalitarian repression which, in so many ways, resembles the one we knew under Hitler's regime'.103 Here, the anti-communist discourse of the early 1950s, comparing Soviet Communism with National Socialism as

97 'Chruschtschows “Geheimrede” vom 25. Februar 1956,' in Entstalinisierung: Der XX. Parteitag der KPdSU und seine Folgen, ed. Reinhard Crusius and Manfred Wilke (Frankfurt a.M.: Suhrkamp, 1977).

98 Bauerkämper, Das umstrittene Gedächtnis, 382.

99 Alexander Szurek, The Shattered Dream (New York: Columbia Univ. Press, 1989), 324-325.

100 Judt, Geschichte, 348.

101 Wilfried Ruppert, Zur Geschichte der Internationalen Föderation der Widerstandskämpfer (FIR) im Kampf für Frieden, Entspannung und Abrüstung, gegen Faschismus und neofaschismus (1951-1970): Zum Anteil der antifaschistischen Widerstandskämpfer der DDR an der Tätigkeit der FIR, 2 vols. (PhD diss., Humboldt-University of Berlin, 1989), vol. 1, 41-42.

102 György Dalos, 1956: Der Aufstand in Ungarn (Bonn: Bundeszentrale für politische Bildung, 2006), 94-95.

103 'La tragedie Hongroise,' Déportation et Liberté, no. 12 (October/November/December 1956). 
both 'totalitarian' in their natures, saw its continuation. The UIRD went one step further and denied the right of the FIR to call itself an organization of resistance fighters, as no one deserved such a title who did not regard the rebels in Budapest in a 'fraternal manner' and who did not protest at 'the extinction by a foreign army of the revolution of a people thirsting for liberty'.104 The WVF broke off contacts with the FIR, too, but unlike the UIRD, this did not happen completely thanks to the membership of the Jugoslav Veterans' Union to which the FIR could establish friendly contacts in 1957 after the rapprochement between the Soviet Union and Tito. ${ }^{105}$ Since the late 1960s, the WVF and the FIR commonly acted for European security, disarmament and peace, organizing several mass meetings of veterans, war victims and former resistance fighters during the 1970 and 1980 s. ${ }^{106}$ In 1971 the FIR also established contact with the FILDIR as well. 107

The incidents of 1956 - the revelations of Khrushchev's 'secret speech', the violent suppression of the protesting workers in Poznan, and the crushing of the Hungarian Revolution - marked the end of the special attraction Soviet Communism had to many in the West. The suppression of the Hungarian uprising plunged the Western communist movement into deep crisis. Many members chose to quit; intellectuals and fellow-travelers turned away; the influence of pro-communist trade unions and similar organizations dramatically dropped. Discussions took place within international pro-communist organizations which had been 'struck a heavy, possibly deadly blow' by the Soviet invasion. ${ }^{108}$ Fierce disputes took place within the FIR as a whole and within its member associations. ${ }^{109}$ Der Widerstandskämpfer published statements indicating that many members of national associations left, although this was never explicitly admitted.110

After the brief thaw from 1954 to early 1957, a clamp-down came in which criticism of the inner development of the Eastern bloc was scarcely permitted, even amongst Western delegates. The FIR was again strongly aligned with

104 'La F.I.R. à Budapest: Une proclamation envers la Résistance Hongroise,' La Voix Internationale de la Résistance: Périodique indépendant, March 1958.

105 Heike Karge, 'Transnational Knowledge into Yugoslav Practices? The Legacy of the Second World War on Social Welfare Policy in Yugoslavia,' Comparativ: Leipziger Beiträge zur Universalgeschichte und Vergleichenden Gesellschaftsforschung 20, no. 5 (2010): 82.

106 Libot, Fédération, 101-113.

107 Ruppert, Geschichte, vol. 1, 162.

108 Judt, Geschichte, $35^{8-359 .}$

109 Tätigkeitsbericht. Sitzung des Büros der FIR, April 5, 1957, 51616/140, DÖW.

110 'Ungarn: Machtvolle Solidaritätskundgebung der Widerstandskämpfer für ihre ungarischen Kameraden,' Der Widerstandskämpfer 4, 11-12 (1956). 
communist politics - indeed, more strongly than before. Although the disputes and loss of members were undoubtedly signs of crisis in the left-wing survivors' movement, the FIR did make some recovery in subsequent years. In 1959, about 200 delegates attended the third congress, showing the strength the organization still had.

Along with continued political commitment, the FIR came to concentrate on historical research and awareness-raising campaigns. In summer 1957, Der Widerstandskämpfer started a new series of articles, entitled 'Pictures of the Resistance Movement' ('Bilder der Widerstandsbewegung'). Starting with Romania, in the following years it presented the official narratives of national resistance movements during the War of virtually every European country. In 1959, it held a congress on 'resistance and the young generation', opening up new avenues for its activities. The congress passed a resolution demanding lessons about the resistance in the school curricula. ${ }^{111}$ The year 1959 saw the launch of a new journal for historians and anyone interested in 'the study of the resistance movement' - the Internationale Hefte der Geschichte der Widerstandsbewegung, published in German and French. ${ }^{112}$ Some prominent historians (mostly communist-leaning) contributed articles. Among them were the Italian Roberto Battaglia, who led the editorial team, the Polish-Jewish Szymon Datner, the East-German Klaus Drobisch and the Austrian Herbert Steiner, later director of the Vienna-based Dokumentationsarchiv Österreichischer Widerstand [Döw; Documentation Center of Austrian Resistance].

De-Stalinization marked the turn to communist nationalism, which replaced the Stalin myth ${ }^{113}$ and with it the transnational resistance myth of the FIR came under scrutiny. In April 1962, the FIR organized an international congress of historians in Warsaw, where the Soviet historian Evgenji Boltin, an employee of the Moscow Institute for Marxism-Leninism, explained ex cathedra that the term 'European resistance [is] wrong..114 At the congress, where Marxist historians set the tone, almost every speaker also emphasized the leading role of the Party. The narrative of the FIR was in contradiction with the communist discourse in two central points: internationality and non-partisanship.

111 Die Widerstandsbewegung und die junge Generation: Internationale Konferenz. Bericht. Florenz, 20.-23. November 1959 (Wien: FIR, 1959). Roberto Battaglia, 'Einführung,' Internationale Hefte der Widerstandsbewegung no. 1, 1 (1959), 3.

113 Pavel Kolář, Der Poststalinismus: Ideologie und Utopie einer Epoche (Köln/Weimar/Wien: Böhlau, 2016).

114 E.A Boltin, '[Stellungnahme zum Hauptbericht],' in Internationale Konferenz über die Geschichte der Widerstandsbewegung: Der nationale und internationale Charakter der Widerstandsbewegung während des Zweiten Weltkrieges (Wien: Internationale Föderation der Widerstandskämpfer, 1962), 219. 
Despite this ideological challenge, the FIR held on to its narrative largely unchanged into the 1980s. Only the meaning and use of the central terms gradually changed with time, but the most important - the non-partisanship, the internationality and the picture of the resistance as a movement spanning classes and social strata - remained largely unchanged. Even the term 'European resistance' was retained. The narrative of the FIR was characterized thereby by a significant element of 'stubbornness' (Alf Lüdke), which was however - even if this is difficult to prove from the files - wanted by the communist parties. The FIR was too important, as an international organization, as connection to the West, and as propaganda tool.

Women continued to play only a role on the periphery, with the FIR remaining a male domain until the end of the Cold War and beyond. This also applies to their inclusion in the memory of resistance. However, when the United Nations declared 1975 'International Women's Year', the FIR welcomed it. In the thirtieth year 'of the victory over the Hitler barbarism', celebrated the same year, the organization recalled for the first time explicitly

the heavy tribute of sufferings, which the women of the whole world paid during the Second World War; of the meaning of the responsibilities, which they took over in their families and in their countries due to the mobilization of the men; of the devotion, which millions of them in all areas of the public life displayed of the self-sacrificing and heroic spirit of others in the resistance, in the ranks of the partisans or the regular armies. Like their comrades, the women resistance fighters were the builders of the freedom of their homeland, of the victory of freedom over oppression, of the victory of human dignity over Nazi barbarism, which wanted to humiliate women into the role of the slavish birthing machine. ${ }^{115}$

Especially the latter was new, because it at least addressed the different experiences of women and men. In the following years, however, such statements did not become the norm.

\section{Conclusion}

Memory of the resistance influenced survivors' political commitments in the postwar period to a substantial degree. Survivors wanted to ensure that

115 Erklärung. Die FIR und das Internationale Jahr der Frau (1975), 10.02.1975, fond 9541, opis 1, dela 1447, GARF. 
fascism and war would never resurface and this resolve stood at the center of most of their activities, be it the protests against German rearmament or their commitment to informing about Nazi crimes and the history of the resistance. For the FIR, the recollection of Nazi crimes or the memory of the humiliating occupation served as a reminder, that West-Germany should be regarded as a constant threat to its neighboring countries, to European security and peace. This use of the past was not limited to the survivors' associations, but it was a common motive in the protests against the EDC in Western Europe. In this way, the communist-led peace movement in France published posters which displayed negative images of Germans and glorified the French Resistance. ${ }^{116}$ The campaign against West-German rearmament was one of the first such campaigns launched by or was involving the FIR. Others were to follow in the decades to come, and all had in common that on the one hand they reflected justified concerns of survivors, while on the other they undoubtedly served propaganda purposes of the socialist countries. Memory also shaped the survivors' self-image as heroes, as an elite and their conviction that they fought for good.

The veterans were split between the two camps of the Cold War and used the memory of the resistance for political aims, while at the same time being themselves put on show in Soviet and Western propaganda and in national official commemorations. A sense of belonging to history gave meaning to their experiences and offered a way of dealing with survivors' trauma. ${ }^{17}$ Furthermore, the veterans' belief that they were paying their duty to the dead by stopping any resurgence of fascism made survival itself a meaningful condition.

Antifascist resistance veterans and concentration camp survivors fostered what they thought of as an inclusive memory. Survivors of the Holocaust were incorporated into the FIR's resistance myth; however, their separate and exceptional fate was not acknowledged, and a fictitious 'unity' of all resistance fighters, regardless of social status or political and religious belief, was stressed. Little attention was given to gender: women were only occasionally mentioned, and the FIR was led exclusively by men. During the 1950s and 196os it was left to specific women survivors' organizations, to preserve the memory of women in wartime resistance.

The media employed to preserve the survivors' memories were commemorations, film festivals, exhibitions and publications. These were representative

116 Sabine Rousseau, "The Iconography of a French Peace Movement: The "Mouvement de la Paix" from the 1950s to the End of the Cold War,' in Peace Movements in Western Europe, Japan and the USA during the Cold War, ed. Benjamin Ziemann (Essen: Klartext, 2007), 195. 
of all the countries involved and aimed to inform the public about the resistance in foreign countries as well as to promote international understanding by creating a common European memory of what the resistance had achieved and still stood for. Art exhibitions and discussions among filmmakers, writers and artists from different countries organized by the FIR on several occasions during the 1950s facilitated an international exchange of ideas and forms of artistic engagement with the resistance. Despite the success of international festivals, the FIR's attempts to foster transnational memory did not attain the lasting impact intended, because of the fissures of the Cold War and the FIR's own emphasis on patriotism and national self-determination both in its campaigns and its memory. Exhibitions were regularly subdivided in national sections and in many cases articles in FIR's journal dealt with the resistance in one respective country. Thus, it spread the respective national versions of the past.

The Hungarian crisis put a temporary stop to all such efforts to achieve harmony and quashed the FIR's attempt to reach a rapprochement with non-communist survivors. Due to its inflexibility over Hungary, the FIR lost much of its credibility, exacerbating the fact that its glory days were already ebbing partly because the number of survivors was dwindling, and partly because the international pro-communist organizations lost their importance for Soviet foreign propaganda after Stalin's death. ${ }^{118}$ Nevertheless, at the end of the 1950s, the FIR did start new initiatives in research and education, and was able to continue its activities into the next decade and beyond.

\section{Acknowledgements}

This article was funded by the Austrian Science Fund (FWF), Project-Number M2284 G-28.

118 Schlaga, Die Kommunisten in der Friedensbewegung, 121-122. 